\title{
Employee Development Practices in Telecom Industry in India - A case study of Public Sector
}

\author{
VasudhaDhingra ${ }^{1}$, Kamlesh Gakhar ${ }^{2}$ \\ ${ }^{I}$ (Research Scholar, IMSAR, Maharshi Dayanand University, Rohtak, India) \\ ${ }^{2}$ (Professor, IMSAR, Maharshi Dayanand University, Rohtak, India)
}

\begin{abstract}
Indian Telecom Industry is more than a century old.It is one of the prime support services needed for rapid growth and modernization of various sectors of the economy. The Indian telecom sector is witnessing great competition. Apart from a several leading private players, MTNL and BSNL are the major public players. Despite the fact that Indian Telecom Industry in public sector has a huge infrastructure and had early mover advantage, still its performance is low as compared to its counterpart in private sector. The increasing concern for the low performance of the public sector and growing discontentment of its personnel has led to an empirical study of public sector telecom industry regarding the employee development practices. For the purpose of analysis, the whole public sector which includes BSNL and MTNL was selected only from the National Capital Region (NCR).A survey instrument was used with a set of fifteen employee development practices to determine the extent of usage of selected practices in the selected units of the public sector. The study brings out the existing picture of employee development practices in the Public sector companies of the telecom Industry in India and offers suggestions to improve the implementation of such practices wherever they need improvement.
\end{abstract}

Keywords: Indian Telecom Industry, Public Sector of Indian Telecom Industry, Public companies: MTNL and BSNL, Employee development practices, Level of implementation of employee development practices;

\section{Introduction}

The telecom services have been recognized the world-over as an important tool for socio-economic development of a nation. It is one of the prime support services needed for rapid growth and modernization of various sectors of the economy. India is the world's second-largest telecommunications market, with 915 million subscribers as of December 2013[1].The Indian telecom sector is witnessing great competition. MTNL (Mahanagar Telephone Nigam Ltd.) and BSNL (Bharat Sanchar Nigam Ltd.) are the major public players, whereas Bharti Airtel, Idea, Vodafone, Tata, Reliance, BPL, Aircel Ltd. are the leading private players in the telecom sector in India. Despite the fact that Indian Telecom Industry in public sector has a huge infrastructure and had early mover advantage, its performance is low as compared to its counterpart in private sector.The financially-stressed public sector telecom companies that together have a debt of Rupees 21,208 crore is facing a declining revenue. BSNL's subscriber market share stands at about 11 per cent as of May, 2014, down from about 15per cent in 2009. On the other hand, MTNL's subscriber share has been halved to 4.8 per cent from about 11 per cent inthe same time [2].In spite of public sector having the inherent advantages of being pioneer in the trade, one of the key factors behind its low performance, is the lack of motivation amongst its human resources. Amongst various reasons cited by different researchers for low motivation and satisfaction of the employees such as: job content, financial rewards, social atmosphere, work life balance, personal characteristics [3] one of the much unexplored reasons is the lack of developmental opportunities. Moreover there is a dearth of study with respect to the employee development practices in the public sector telecom companies in India. Due to that reason, the present study was designed to have an insight into the implementation of Employee development practices in the public sector units of the telecom industry and to find the lacunae. The research undertaken certainly throws light upon various aspects where the top level management in public sector telecom companies needs to work out. It sheds light on desirable employee development practices that human capital practitioners could develop to create competitive advantage through their human capital assets by determining what, where, and how improvements may be effected in the overall interest of the companies concerned.

\subsection{Indian telecom industry}

Indian telecom sector is more than 160 years old. It started when the East India Company had introduced telegraph services in India, beginning with commissioning of the first telegraph line between Kolkata and Diamond Harbor in 1839. In 1948, India had only 0.1 million telephone connections with a telephone density of about 0.02 telephones per hundred population. Since then, India has come a long way. According to TRAI report 2014[1], total number of mobile phone subscribers reached 915 million at the end of 
December2013. The mobile tele-density had increased to $74.02 \%$ in December 2013. Telecom services in India can be basically divided into two major segments:

a) Telephones, Wireline and wireless

b) Internet services

\subsection{Emergence of public and private service providers}

Telecom services and most of the manufacturing activities related to the sector were totally under the Government domain till telecom reforms began in the 1980s with the launch of the "Mission Better Communication" programme. Private manufacturing of equipment for customers' use was allowed in 1984 and the Centre for Development of Telematics (C-DOT) was established for the development of indigenous technologies. Two large corporate entities were spun off from DoT, viz, the Mahanagar Telephone Nigam Limited (MTNL) in February 1986 for Delhi and Mumbai and the Videsh Sanchar Nigam Limited (VSNL) in March 1986 for all international services. As a part of the continuing process of telecom reforms and in pursuance of the New Telecom Policy 1999 (NTP-99), the Department of Telecom Services (DTS) and the Department of Telecom Operations (DTO) were carved out from DoT in October 1999 for providing telecommunication services in the country. DTS and DTO were finally corporatized into a wholly owned Government Company, namely, the Bharat Sanchar Nigam Limited (BSNL) incorporated on 15 September 2000and their business was transferred to this Company with effect from 1 October, 2000. The creation of BSNL was expected to provide a level playing field in all areas of telecom services, between government operators and private operators. The entry of private service providers brought with it the inevitable need for independent regulation. The Telecom Regulatory Authority of India (TRAI) was, thus, established with effect from 20th February, 1997 by an Act of Parliament, called the Telecom Regulatory Authority of India Act, 1997, to regulate telecom services, including fixation/revision of tariffs for telecom services.

\subsubsection{Mahanagar Telephone Nigam Ltd (MTNL)}

MTNL is a state owned Indian telecom services provider. It provides a range of telecom services including fixed line, mobile, broadband and national and international long distance. At the end of March 2013, the company had 1.12 million broadband subscriptions, 4.99million mobile subscriptions and 3.46 million fixed line subscriptions.

\subsubsection{Bharat Sanchar Nigam Ltd. (BSNL)}

Bharat Sanchar Nigam Limited is a state-owned telecommunications company headquartered in New Delhi, India. BSNL is one of the largest Indian cellular service providers, with over 83.6 million subscribers as of January 2011, and the largest land line telephone provider in India.BSNL, then known as the Department of Telecommunications, had been a near monopoly during the socialist period of the Indian economy. During this period, BSNL was the only telecom service provider in the country. MTNL was present only in Mumbai and New Delhi. During this period BSNL operated as a typical state-run organization, inefficient, slow, bureaucratic, and heavily unionized. As a result subscribers had to wait for as long as five years to get a telephone connection. The corporation tasted competition for the first time after the liberalization of Indian economy in 1991. Faced with stiff competition from the private telecom service providers, BSNL has subsequently tried to increase its efficiency.. The corporation (then DoT), however, failed to achieve the egalitarian growth and India languished among the most poorly connected countries in the world. BSNL was born in 2000 after the corporatization of DoT. The corporatization of BSNL was undertaken by an external international consulting team consisting of a consortium of A.F.Fergusonand Co, JB Dadachanji and NM Rothschild - and was probably the most complex corporatization exercise of its kind ever attempted anywhere because of the quantum of assets (said to be worth USD 50 billion in terms of breakup value) and over half a million directly and indirectly employed staff. Satish Mehta, who led the team, later confessed that one big mistake made by the consortium was to recommend the continuation of the state and circle based geographical units which may have killed the synergies across regions and may have actually made the organization less efficient than had it been a seamless national organization [4]. Vinod Vaish, then Chairman of the Telecom Commission, made a very bold decision to promote younger talent from within the organization to take up a leadership role and promoted the older leaders to a role in licensing rather than in managing the operations of BSNL. The efficiency of the company has since improved, however, the performance level is nowhere near the private players [4]. In order to sustain the continuous growth and market share of the public sector of the Indian telecom industry, the need for trained professionals is bound to rise and so is the training need. Thus employee management and development evolved as the significant key success factors. 


\section{Literature Review}

According to the survey carried out by HOST last year the mostpopular reason for introducing an employee development system is to encourage learningin the work environment and create a learning culture. The second motive for introducing employee development is to enhance the skills to provide professional and personal development and the third purpose is to inculcate a sense of commitment and loyalty [5].

Learning and development is an important factor increating a sense of progression and purpose that leads to organizational commitment [6]. It was found that training positively impacts productivity, which results in higher level of customer and employee satisfaction thus increasing brand value [7]. Aligned with the aforementioned researchers'findings Michael and Combs [8] in their study, revealed that training can reduce probability of failure as training affects performance, enlarges the skill base and develops the level of competence. It helps in developing climate for learning which not only aids in training to flourish but also supports self-managed learning practices [9].As a matter of fact employee development needs to be an integral part of the corporate objectives and its role is to help employees meet organizational goals through the achievement of their personal goals [10].

In a study, a comparison of firms that are committed, against firms that are non-committed to training and development was done and the results yielded showed that training and development not only positively impacted job performance but also aided in improving employee ability to manage stress at work [11]. Similarly in another study on Spanish companies foundorganizationallearning to be a mediator in high performance of human resource and business performance [12].

Six studies examined the telecommunication industry which has been transformed by the twin forces of technological change and deregulation (including privatization) since 1984. Five of these are empirical studies, while one of them [13]provides a summary of empirical studies examining four telecom privatizations. These studies generally indicate that deregulation and liberalization of telecom services are associated with significant growth in tele-density and operating efficiency, and significant improvements in the quality and reduced price of telecom services. This scenario suggests that eventually the public sector will have a shortage of young skilled employees.Research has revealed that the public and private sectors are distinct in terms of vision, ownership, markets, values, performance expectations or strategic constraints [14]. These differences have shaped the environmental context of both sectors. In particular, the public sector environment is characterised by an absence of competitive pressures, an open systems character, and the predominant control by political forces instead of market forces [15].

\section{Research Methodology}

The present study was undertaken to pursue the following broad objective:

1. To assess and compare the extent of implementation of selected employee development practices in the public sector units of the telecom industry in India.

A structured questionnaire was used to gather the desired information. The whole public sector which includes BSNL and MTNL from the National Capital Region (NCR) was selected for the purpose of analysis. A total of 18 districts in three neighbouring states of Haryana, Uttar Pradesh and Rajasthan along with whole of the National Capital Territory of Delhi constitute the National Capital Region (NCR) of India as defined in National Capital Region Planning Board (NCRPB) Act, 1985 [16] Primary data were collected from the junior, middle and senior level employees working in the selected units of the telecom industry. The response was collected from 120 employeescomprising of50 employees from MTNL and 70 employees from BSNL.The survey instrument to measure the employee development practices was adapted from the "Employee Development Survey Report, 2005" [17]. According to the instrument employee development was defined as improving employee competencies and skills over the long term, through a variety of methods such as mentoring, coaching, succession planning, identification of high-potential employees, etc. Fifteen employee development practices were included in the instrument. Some of the practices were modified according to the telecom industry after conducting the pilot test on this instrument.

The instrument was used to measure the extent of implementation of the selected practices. Several researchers have mentioned that awell-planned training program should be run all throughout the life of the organization, or it should be an ongoing process [18];[19]. There has been no specific explanation for the level of implementation of a particular training and development practice. Different viewpoints explain the level of implementation of a development program. For instance according to the survey results of one of the studies on HR scorecard [20], organizations with high HRM quality have a higher percentage of employees in a formal plan for development, and both new and experienced employees spend more hours in training each year.This is supported by another research [18], which stated, 'probably, at minimum, everyone in the organization should have the opportunity for some ongoing training at least once a month. Some organizations may conduct or sponsor ongoing training much more often, sometimes as part of a weekly or biweekly staff meeting'. Adding to this a research mentioned the participation in a learning program [21]. According to it 'participation in self- 
directed learning seems almost universal;in fact, an estimated 90 percent of the population is involved with at least one self-directed learning activity a year'. Thus based on the theory it is put forwardthat,a development practice implemented once in a year is considered to be somewhat frequent implementation of the practice. Any practice taking place once in more than 12 months is considered to be happening occasionally, rarely or vary rarely in the order of increasing months and similarly any development practice happening more than once a year is considered to be used frequently or very frequently in order of the decreasing months. Respondents were asked to specify each practice a seven point Likert Scale (1-Never, 2- once in more than 24 months, 3- once in 24 months, 4 - once in 18 months, 5 - once in 12 months, 6 - once in 6 months, and 7- once a month).

\subsection{Hypothesis}

H01: There is no difference in the perception of the employees towards theexisting employee development practices in the selected units of the public sector of thetelecom industry.

To test the above hypothesis firstly the descriptive statistics were used where the mean score for each of the employee development practice understudy was calculated for both the companies belonging to the public sector. Then to find the difference between the companies the means were compared by using independent $\mathrm{t}$ test method. The independent sample $t$ test was run using an alpha level of 0.05 , to determine if there was a significant difference in the level of implementation of the employee development practices in the two companies of the public sector of the telecom industry. Leven's Test was conducted to assess for equality of variances of the items. For those items whose homogeneity of variances was violated Welch Satterthwaite corrections were used.

\section{Data Analysis}

Present study is an attempt to assess current employee development practices followed in the public sector organizations of the telecom industry. Respondents were presented with a list of fifteen development activities and asked to provide ratings of each in terms of their perception of the implementation for these development practices. Each development activity was rated in terms of the extent to which it is available.

\subsection{Public Sector of Telecom Industry}

Following table shows the mean scores of the implementation of employee development practices in the public sector of the Telecom Industry.

Table 1: Mean Scores of the Implementation of Employee Development Practices in the Public Sector

\begin{tabular}{|c|c|c|c|c|c|c|c|}
\hline S.No. & $\begin{array}{c}\text { Employee Development } \\
\text { Practices }\end{array}$ & $\begin{array}{c}\text { Public } \\
\text { Sector }\end{array}$ & Rank & MTNL & Rank & BSNL & Rank \\
\hline V1 & Apprenticeship & 2.50 & 5 & 2.52 & 4 & 2.49 & 4 \\
\hline V2 & Cross-cultural training & 1.85 & 10 & 1.86 & 12 & 1.84 & 8 \\
\hline V3 & Development appraisal & 2.06 & 6 & 2.12 & 6 & 2.01 & 6 \\
\hline V4 & Coaching and mentoring & 1.87 & 9 & 2.10 & 7 & 1.70 & 10 \\
\hline V5 & Career planning & 1.67 & 13 & 1.72 & 13 & 1.63 & 11 \\
\hline V6 & Succession planning & 1.68 & 12 & 1.86 & 10.5 & 1.56 & 13 \\
\hline V7 & High visibility assignment & 2.89 & 1 & 2.82 & 2 & 2.94 & 2 \\
\hline V8 & Job rotation & 2.57 & 4 & 2.58 & 3 & 2.56 & 3 \\
\hline V9 & Job sharing & 2.66 & 3 & 3.16 & 1 & 2.30 & 5 \\
\hline V10 & Behavioural training & 1.88 & 8 & 2.00 & 8 & 1.80 & 9 \\
\hline V11 & Leadership training & 1.97 & 7 & 1.98 & 9 & 1.96 & 7 \\
\hline V12 & E- learning & 2.72 & 2 & 2.38 & 5 & 2.96 & 1 \\
\hline V13 & Self directed learning & 1.71 & 11 & 1.86 & 10.5 & 1.60 & 12 \\
\hline V14 & Stretch assignment & 1.50 & 14 & 1.52 & 14 & 1.49 & 14 \\
\hline V15 & Stress training & 1.22 & 15 & 1.42 & 15 & 1.07 & 15 \\
\hline
\end{tabular}

Source: Survey Data

The results of the mean scores (Table 1) for the implementation of the fifteen employee development practices in the public sector of the telecom industry in India shows High visibility assignment is the most frequently used practice amongst all the practices with the mean score of 2.89. This is followed by E-Learning with mean score 2.72 and Job Sharing with mean score 2.66 and Job Rotation with the average score 2.57. Apprenticeship (MS= 2.50) occupied the 5th rank. After these comes Development appraisal with the mean score 2.06. Then comes Leadership training, Behavioural training and Coaching and mentoring with the mean score of $1.97,1.88$ and 1.87 respectively. This is 
followed by Cross-cultural training with mean score 1.85 . The least frequently followed five practices in the public sector are Self directed learning $(\mathrm{MS}=1.71)$, Succession planning $(\mathrm{MS}=1.68)$, Career planning (MS=1.67), Stretch assignment $(\mathrm{MS}=1.50)$, and Stress training $(\mathrm{MS}=1.22)$.

Since the scale is a seven point scale used to determine the implementation of the employee development practices, the average score for the scale is calculated to be four. It is found that the mean scores for all fifteen practices are below the average score. Thus from the above results it is implied that in the public sector the selected employee development practices are on an average being implemented once in more than 24 months. Accordingly the frequency of the employee development practices in the public sector is found to be rare.From the mean scores (Table 1) of the two selected companies of the public sector it is foundthat the mean scores for the employee development practices (V1, V2, V3, V4, V5, V6, V8, V9, V10, V11, V13, V14, $\mathrm{V} 15)$ are higher for MTNL as compared to BSNL. And the mean scoresfor V7 and V12 are found to be higher in case of BSNL. This indicates that except Highvisibility assignment and E-learning which are more often used in BSNL the rest of 13 developmentpractices are more frequently used in MTNL as compared to BSNL in public sector of thetelecom industry.

\subsection{Comparative Analysis of Mean Scores of Implementation of Employee Development Practices in the Public Sector Units of the Telecom Industry}

Table2 showsthe mean scores of the implementation of employee development practices in both public sector companies of the Telecom Industry along with $t$ test.Using an alpha level of 0.05 , an independent sample t-test was run which explained that, the variations in the use of various practices like Apprenticeship, Crosscultural training, Development appraisal, Coaching and mentoring, Career planning, Succession planning, Highvisibility assignment, Job rotation, Behavioural training, Leadership training, E- learning, Self directed learning, Stretch assignment in public sector companies have been insignificant. This implies that the above practices do not act as differentiator for their frequency of implementation between MTNL and BSNL. The difference in the usage of these practices occurs by chance. On the other hand Job Sharing in the public sector seems to be higher in frequency in MTNL with the mean score of 3.16. Although below average, it is the most frequently used practice when compared with other practices. In BSNL, it is rarely being followed with the mean score of 2.30. But here unlike other practices the difference in the mean scores for the frequency of the practice in the two companies is found to be significant as indicated by the $p$ value 0.00 which is less than 0.05 (Table 2).

Table 2: Mean Scores of Implementation of Employee Development Practices in the Public Sector Units

\begin{tabular}{|c|c|c|c|c|c|}
\hline S.No. & $\begin{array}{c}\text { Employee Development } \\
\text { Practices }\end{array}$ & MTNL & BSNL & t- value & $\begin{array}{c}\text { Significance Level } \\
\text { p-value }\end{array}$ \\
\hline V1 & Apprenticeship & 2.52 & 2.49 & 0.17 & 0.87 \\
\hline V2 & Cross-cultural training & 1.86 & 1.84 & 0.07 & 0.95 \\
\hline V3 & Development appraisal & 2.12 & 2.01 & 0.31 & 0.75 \\
\hline V4 & Coaching and mentoring & 2.10 & 1.70 & 1.28 & 0.20 \\
\hline V5 & Career planning & 1.72 & 1.63 & 0.38 & 0.71 \\
\hline V6 & Succession planning & 1.86 & 1.56 & 1.06 & 0.29 \\
\hline V7 & High visibility assignment & 2.82 & 2.94 & -0.45 & 0.66 \\
\hline V8 & Job rotation & 2.58 & 2.56 & 0.09 & 0.93 \\
\hline V9 & Job sharing & 3.16 & 2.30 & 3.04 & $0.00 * *$ \\
\hline V10 & Behavioural training & 2.00 & 1.80 & 0.95 & 0.34 \\
\hline V11 & Leadership training & 1.98 & 1.96 & 0.07 & 0.94 \\
\hline V12 & E- learning & 2.38 & 2.96 & -1.79 & 0.08 \\
\hline V13 & Self directed learning & 1.86 & 1.60 & 0.89 & 0.38 \\
\hline V14 & Stretch assignment & 1.52 & 1.49 & 0.19 & 0.85 \\
\hline V15 & Stress training & 1.42 & 1.07 & 2.33 & $0.02 * *$ \\
\hline **p value $<0.05$ & & & & \\
\hline
\end{tabular}

The mean score of stress training in MTNL $(\mathrm{MS}=1.42)$ is higherthan in BSNL $(\mathrm{MS}=1.07)$. But the implementation is very less as far as the mean score isconsidered. And the difference in the mean score in MTNL and BSNL for this practice is found to be significant when the $t$ test is run at 0.05 alpha value, the pvalue is found to be statisticallysignificant $(\mathrm{p}=0.02)$ (Table 2$)$. Thus overall the implementation of this practice in the public sector is found to be the least. 


\section{Results and Interpretations}

A considerable amount of literature supports the contention that public firms aremore rule oriented, more hierarchical and more bureaucratic than are private firms [22]. Also it was opined in studies [23]; [24] that the public sector employees arecharacterized of having a reputation for being lazy and lethargic. This explains the below average implementation of all the selected practices in both the companies of the public sector. This means that the employers are not makingthe requiredeffort for the development of the employees. Even the employees are not self-motivated to participate or put up the requirement for training. According to one of the senior officials at BSNL," BSNL provides need based training. For instance if an employee has to be promoted to the higher post, he is provided training. In other case, if any new software is introduced in the system e.g. ERP then training is provided to learn about the software."The independent $t$ test at alpha value 0.05 comes out to be statistically insignificant for almost all the selected practices. This shows how the environment and culture followed in the two companies of the public sector are similar and overlapping.

Apart from this, the public sector faces challenges in implementing succession planning and career planning and leadership training. The longtenures of the employee service in this sector on the same position givesthem almost a permanent status. In MTNL and BSNL, the employees have experienced 15 yearsof servicing at the same position. The prolonged stay in public sector hampering the development of an employee, has also been mentioned by different researchers. Various challenges in implementingsuccession planning in the public sector include the nature of tenure and political leadership inthe public sector, personnel system rules, lack of resources and lack of focus [25];[26]. This is supported by a study on public sector employees [27], which says that Baby boomers, who work in the public sector, are today in the pinnacle oftheir career, but this generation is experiencing bans on promotions, extreme competition for toppositions, and a freeze of wages [28]. Public employees, who were supposed to be intheir highest fertility years, are now doomed for a career gridlock and plateauing promotions[27].The reason for this finding is that most public sector organizations continue to place great emphasis on technical expertise across all of the organization's operations, ranging from positiondescriptions and trainings to advancement and leadership opportunities, while providing little orno leadership training [29].

The sector shows a low implementation of development programmes like stretch assignments, selfdirected learning. It has also been mentioned clearly in a study that the type of business is one of the variables affecting self-directedlearningefforts [30]. The results of the study showed that positive organizational climate enhanced self-directedlearning. Public sector organizations emphasized the negative influence of theorganizational process and the structure of self-directed learning. From the workcontext point of view,a research found that public employees are first and foremostmotivated by job security and stability [31], In a 2007 study, it was reaffirmedand concluded that "public sector workers are strongly motivated by thedesire to work in a supportive working environment" [32]. These simply support that public sectoremployees do not want to come out of their comfort zone of work and opt for stretch assignments

The difference between the implementation of two practices in MTNL and BSNL are found to be statisticallysignificant. The two practices are Job sharing and Stress training. The most probable reason for this is, that the number of employees in MTNL is 57000 which is far less than BSNL where the number of employees is 244 891, as on 19th November 2013. Thus there would be expected sharing of work amongst the employees of MTNL.Hence there is difference between thelevel of implementation in the two companies. Another reason is the pay scale disparity. The MTNL employees are getting one scale above from the BSNLemployees. MTNL executives' pay scale starts from E-2 scale whereas BSNL executives'pay scales started from E-1A which is an intermediate lower scale. Obviously with the more pay scale the MTNL employees are expected to share a lot of work. Since the work pressure is more in MTNL the employees are more prone to stress. Hence the more use of Stress Training.

\section{Conclusions and Recommendations}

The results of this research contribute to knowledge about Employee Development Practices specifically to the public sector of the Telecom Industry. A rare implementation of employee development practices has been found in the sector. The paper has contributedin providing a close examination of thedifference in the implementation of the different Employee development practices in the twocompanies of the public sector. It was found that that except High visibility assignment, and E-learning which are more often used in BSNL, rest 13 development practices are more frequently used in MTNL as compared to BSNL in public sector of the telecom industry. The results also showed that difference in the level of implementation of Job rotation, Leadership training, and E-Learning, have beenstatistically insignificant at $5 \%$ significance level in terms of the perception of the employeestowards the existing practices. This implies that the above practices do not act as differentiatorbetween MTNL and BSNL, the two public sector companies under study. The difference in thesepractices occurs by chance. This accepts the underlying null hypothesis for these three practices. For Apprenticeship, Cross-cultural training, Development appraisal, Coaching and mentoring,Career planning, 
Succession planning, High visibility assignment, Job sharing, Behaviouraltraining, Self-directed learning, Stretch assignment and Stress training, the null hypothesis is accepted.

An examination of the group means indicated that the top five practices which are often used in MTNL are Job sharing, High visibility assignment, Job rotation, Apprenticeship, and E-learning, whereas the least frequently used five practices are Succession Planning, Cross-cultural training, Career planning, Stretch assignment, and Stress training

As seen in BSNL the top five the practices are E-learning, High visibility assignment, Job rotation, Apprenticeship, and Job sharing, whereasthe least ones are Career mentoring, Self directed learning, Succession Planning, Stretch assignment, and Stress training.

Despite all the earnest attempts to elicit all required data on employee development practices in public sector telecom Industry, the study is subject to certain limitations due to the fact that the data is based on individual opinions, which may bring in some bias. Due to the constraint of time the area of study was restricted to National capital region only. Moreover, the sample size is confined to the responses of 120 employees only; therefore, the conclusions drawn cannot be generalized for all the entire public sector. In addition to this, most of the respondents were reluctant in expressing their opinion freely without any hesitation and showing lack of interest in responding. As the questionnaire is based on gauging the perception of the employees, the same may have posed a threat to internal validity of the conclusions drawn. Further, the opinion of some of the employees turns out to be influenced by their peer employees or superiors which might lead to their neutral response to a large extent for several statements.

The employees working in the public sector of the telecom industry agree that development practice in the public sector companiesshould not be a one-time affair, but it should be continuous. According to the respondents there is lack of retraining. This eventually reduces the frequency of the development practices. Development programmes are not systematically planned. They are according to the need of the situation .The public sector companies need to step up their outlay on employee development and training. The number of hours devoted should be gradually increased. With the Government of India extending hands to bring the loss making units on their feet, the public sector units will be getting a massive investment over the next five years. The management should seek benefits of this step in improving the implementation of employee development plans. These recommendations if implemented properly will go a long way to help the management of public sector telecom companies in India in the smooth working of the organization.

[1] TRAI Report, The Indian Telecom Service Performance Indicators. Retrieved from http://www.trai.gov.in/ WriteReadData/PIRReport/Documents/Indicator\%20Reports\%20-\%20Mar-14.pdf, 2014.

[2] M Ozaki, Y. Adachi, Y. Iwahori, and N. Ishii, Application of fuzzy theory to writer recognition of Chinese characters, International Journal of Modelling and Simulation, 18(2), 1998, 112-116.

[3] S.K. Sokoya, Personal predictors of job satisfaction for the public sector manager: Implications for management practice and development in a developing economy. Journal of business in developing nations, 4(1), 2000.

[4] R. Singh, Telecom PSU's on a drip. Retrieved from http://www.voicendata.com/voice-data/news/167589/telecom-psus-drip, 2012

[5] D.J. Parsons, N. Cocks, and V. Rowe, The Role of Employee Development Schemes in Increasing Learning at Work. HOST Survey Research report no. 73, DfEE, 1998.

[6] M. Armstrong, Armstrong Handbook of Human Resource Management Practice. 11th Ed.(London:Kogan page, 2009).

[7] S. Choo, and C. Bowley, Using training and development to affect job satisfaction within franchising. Journal of Small Business and Enterprise Development, 14(2), 2007, 339-352.

[8] S.C. Michael, and J.G. Combs, Entrepreneurial Failure: The Case of Franchisees. Journal of Small Business Management, 46(1), 2008, 73-90.

[9] M. Armstrong, Human resource management practice. (London:Kogan page, 2006).

[10] S. Milonakis, and M. Zairi, Benchmarking for best practices in employee development. Training for Quality, 2(3), 1994, 28-33.

[11] T. Acton, and W. Golden, Training the knowledge worker: a descriptive study of training practices in Irish software companies. Journal of European Industrial Training, 27(2/3/4), 2003, 137-146.

[12] S.P. López, J.M.M.Peón, and C.J.V.Ordás, Human resource practices, organizational learning and business performance. Human Resource Development International, 8(2), 2005, 147-164.

[13] R. Ramamurti, Testing the limits of privatization: Argentine railroads. World Development, 25(12), 1997, 1973-1993.

[14] C.E. Hull, and B.H.Lio, Innovation in non-profit and for-profit organizations: Visionary, strategic, and financial considerations. Journal of Change Management, 6(1), 2006, 53-65.

[15] H.G. Rainey, R.W.Backoff, and C.H. Levine, Comparing public and private organizations. Public Administration Review, 1976, 233-244.

[16] National Capital Region Planning Board. Ncrpb.nic.in. Retrieved on 2013-07-16.

[17] E. Esen, and J. Collison, Employee Development Survey Report A Study by the Society for Human Resource Management and Catalyst. (United States: SHRM, 2005).

[18] P. Rabinowitz, Developing Training Programs for Staff. Community Tool Box, Retrieved from http://ctb.ku.edu/en/table-ofcontents/structure/hiring-and-training/training-programs/main, 2013

[19] R. Bean, Cross-Cultural Training and Workplace Performance (National Centre for Vocational Education Research Ltd. PO Box 8288, Stational Arcade, Adelaide, SA 5000, Australia, 2008).

[20] B. Becker, M. Huselid, and D. Ulrich, D. (2001). The HR scorecard: Linking people, strategy, and performance (Boston: Harvard Business School, 2001)

[21] S.B. Merriam, R.S. Caffarella, and L.M. Baumgartner, Learning in adulthood: A comprehensive guide. (John Wiley \& Sons, 2012) 
[22] P.G. Scott, and S. Falcone, Comparing Public and Private Organizations An Exploratory Analysis of Three Frameworks. The American Review of Public Administration, 28(2), 1998, 126-145.

[23] J.Q.Wilson, Bureaucracy: What Government Agencies Do and why They Do it (New York: Basic Books,1989)

[24] B.E.Wright, Public-sector work motivation: A review of the current literature and a revised conceptual model. Journal of public administration research and theory, 11(4), 2001, 559-586.

[25] B. Wilkerson, B. Effective Succession Planning in the Public Sector. North America. Retrieved from http://www.4cleanair.org/chicago/EffectiveSuccessionPlanningforPublic.pdf. 2007

[26] J.C. Santora, and J.C. Sarros, Mortality and leadership succession: a case study. Leadership \& Organization Development Journal, 16(7), 1995, 29-32.

[27] Y. Re'em, Motivating Public Sector Employees: An application Oriented Analysis of Possibilities and Practical Tools. (Doctoral Dissertation, Hertie School of Governance, Berlin, 2011)

[28] J.F. Wolf, Career plateauing in the public service: Baby boom and employment bust. Public Administration Review, 43(2), 1983, $160-165$.

[29] R.S. Morse, and T.F. Buss, Innovations in Public Leadership Development. (Armonk, N.Y.: M.E. Sharpe, 2008)

[30] W.J. Kops, Managers as self-directed learners: Comparing findings of studies in private and public sector organizations. Expanding horizons in self-directed learning, 1997,71-86.

[31] C.L. Jurkiewicz, T.K. Massey Jr, and R.G. Brown, Motivation in public and private organizations: A comparative study. Public Productivity \& Management Review, 21(3), 1998, 230-250.

[32] M. Buelens, andH.Van den Broeck, An analysis of differences in work motivation between public and private sector organizations. Public Administration Review, 67(1), 2007, 65-74. 